\title{
Spread of metals through an invertebrate food chain as influenced by a plant that hyperaccumulates nickel
}

\author{
Lynsey R. Peterson ${ }^{1}$, Victoria Trivett ${ }^{2}$, Alan J. M. Baker ${ }^{2,3}$, Carlos Aguiar ${ }^{4}$ and A. Joseph Pollard ${ }^{1}$ \\ ${ }^{1}$ Department of Biology, Furman University, Greenville SC 29613, USA \\ ${ }^{2}$ Department of Animal and Plant Sciences, University of Sheffield, Sheffield S10 2TN, UK \\ ${ }^{3}$ School of Botany, University of Melbourne, Melbourne, Victoria 3010, Australia \\ ${ }^{4}$ Departamento de Biologia, Escola Superior Agrária de Bragança, Aptdo 1172, 5301-855 Bragança, Portugal
}

\begin{abstract}
Summary. Hyperaccumulation of metals in the shoot system of plants is uncommon, yet taxonomically and geographically widespread. It may have a variety of functions, including defense against herbivores. This study investigated the effects of hyperaccumulation on metal concentrations across trophic levels. We collected plant material, soil, and invertebrates from Portuguese serpentine outcrops whose vegetation is dominated by the nickel hyperaccumulator Alyssum pintodasilvae. Samples were analyzed for nickel, chromium, and cobalt. Grasshoppers, spiders, and other invertebrates collected from sites where A. pintodasilvae was common had significantly elevated concentrations of nickel, compared to nearby sites where this hyperaccumulator was not found. Chromium and cobalt, occurring in high concentrations in the serpentine soil but not accumulated by A. pintodasilvae, were not elevated in the invertebrates. Therefore, it appears likely that a flux of nickel to herbivore and carnivore trophic levels is specifically facilitated by the presence of plants that hyperaccumulate this metal. The results may be relevant to the development of phytoremediation and phytomining technologies, which use plants to extract metals from the soil.
\end{abstract}

Key words. Hyperaccumulation - trace elements - phytoremediation - phytomining - Alyssum

\section{Introduction}

Hyperaccumulation of metals is known from about 400 species of flowering plants, which take up, transport and sequester metallic elements, achieving tissue concentrations that are toxic to most organisms (Baker et al. 2000; Reeves \& Baker 2000). Several hypotheses have been advanced to explain the evolution of this trait (Boyd \& Martens 1992), with most attention focused on the hypothesis that hyperaccumulated metals may act as defenses against herbivory (Boyd 1998; Boyd \& Martens 1998; Pollard 2000; Pollard et al. 2000). With the exception of recent work by Wall

Correspondence to: A. J. Pollard, e-mail: joe.pollard@furman.edu and Boyd (2002), most studies to date have considered interactions between individual plants and herbivores, with little attention paid to the effects of hyperaccumulators on their communities or ecosystems.

The broader environmental consequences of hyperaccumulation are of practical importance because of developing technologies that would use metal-accumulating plants to cleanse contaminated soil, termed phytoremediation (Cunningham \& Ow 1996; Chaney et al. 1997; Salt \& Baker 2001; Schwitzguébel et al. 2002), or use such plants to extract commercially valuable metals from low-grade ores, termed phytomining (Brooks et al. 1998). A relatively unexplored risk of these techniques is that metals sequestered in plant tissues could be consumed by herbivores and thus mobilized into food chains (US Dept of Energy 1994; Chaney et al. 2000). One way to investigate the possibility of such mobilization is through studies of natural ecosystems whose vegetation is dominated by hyperaccumulating plants.

We conducted our study at Portuguese serpentine (ultramafic) sites, whose soils are typically high in nickel, chromium, cobalt, and magnesium, but relatively deficient in calcium, potassium and phosphate. Such sites possess distinctive vegetation with high levels of endemism (Brooks 1987; Chiarucci et al. 1998). Alyssum pintodasilvae Dudley (syn. A. serpyllifolium ssp. lusitanicum Dudley \& Pinto da Silva; cf. Dudley 1986) is a member of the Brassicaceae (mustard family) that is endemic to serpentine outcrops in northeastern Portugal, where it can represent a very large proportion of the vegetation (Aguiar et al. 1998). Plants of this species are known to hyperaccumulate nickel in such systems (Brooks et al. 1981; de Varennes et al. 1996). The research reported here was designed to investigate the effects of this hyperaccumulation on the trace element levels in invertebrate communities.

\section{Materials and methods}

We collected replicate sets of soil, plant, and invertebrate samples from five sites where A. pintodasilvae makes up at least $50 \%$ of plant cover (designated $\mathrm{Ap}+$ ) and five other areas where it is absent (designated Ap-). Collections were made on August 15-16, 1999, 
from two localities in northeastern Portugal in the vicinity of Bragança (N41 46'41.7', W6 ${ }^{\circ} 45^{\prime} 4.2^{\prime \prime}$ near Samil and N41 $50^{\prime} 34.8^{\prime \prime}, \mathrm{W} 6^{\circ} 51^{\prime} 42.1^{\prime \prime}$ on the N103 at the Gondesende junction), with both Ap+ and Ap- sites in each locality. Site characteristics are described in Table 1.

Soils were collected from the top $5 \mathrm{~cm}$ of the soil, adjacent to the plant root systems. Samples of A. pintodasilvae foliage were collected in sites where it was present, and separate samples of other representative plants were collected at all sites. Invertebrates were collected by sweep-netting along a $4 \times 50 \mathrm{~m}$ strip transect, with two passes made along each transect. (In two cases where rocky terrain and thorny shrubs prohibited transect sampling, we sweep-netted in and around patches of A. pintodasilivae for a period of 4 minutes, which was determined to be the approximate time spent sampling the transects.)

Invertebrates were sorted into three groups: grasshoppers, spiders, and "other invertebrates." Mass requirements for metal analysis prevented us from dividing the groups further; for this reason many of the invertebrates were not taxonomically identified. Grasshoppers and spiders were separated because each was a relatively abundant group and because they represent exclusively herbivorous and carnivorous groups, respectively.

Plants and animals were dried, weighed, ashed at $500^{\circ} \mathrm{C}$, and dissolved in $10 \% \mathrm{HCl}$. Soil samples were sieved, dried, weighed, and digested in concentrated $\mathrm{HNO}_{3} / \mathrm{HCl}$. Extracts were analyzed for $\mathrm{Ni}, \mathrm{Cr}, \mathrm{Co}$, and $\mathrm{Zn}$ using flame atomic absorption spectrophotometry. There were few significant differences in $\mathrm{Zn}$ concentration among the samples, and they are not reported here.

Two-tailed Mann-Whitney U tests were used to test the significance of differences in mean metal concentration between sites where A. pintodasilvae was present and those where it was absent. This non-parametric test was employed because of large differences in variance between treatment groups, especially in cases where metal concentrations were near the limits of instrumental detection.

\section{Results}

Plants other than Alyssum pintodasilvae consistently had concentrations of $\mathrm{Ni}, \mathrm{Cr}$, and $\mathrm{Co}$ that were about $0.3 \%$ to $0.6 \%$ of the respective elemental concentrations in the soil in which they grew (Table 2). The mean Ni concentrations in A. pintodasilvae leaves were approximately $5,600 \mathrm{mg} \mathrm{kg} \mathrm{kg}^{-1}$ (dry weight), more than 2.5 times the total concentration in the soil. On the other hand, concentrations of $\mathrm{Cr}$ and $\mathrm{Co}$ were only slightly if at all higher in A. pintodasilvae than in other nearby plants (Table 2), and about two orders of magnitude lower than their concentrations in soil.

Soils covered by $A$. pintodasilvae had higher concentrations of $\mathrm{Ni}, \mathrm{Cr}$, and $\mathrm{Co}$ than those where it was not present (Table 2). These differences were statistically significant for all three metals (Mann-Whitney $\mathrm{U}$ test: $\mathrm{P}=0.001$ for $\mathrm{Ni}$, $\mathrm{P}=0.012$ for $\mathrm{Cr}, \mathrm{P}=0.004$ for $\mathrm{Co}$ ). The Ni content of plants other than $A$. pintodasilvae essentially mirrored these soil differences, with each element about 1.5 to 2 times more concentrated in the plants sampled from Ap+ sites than in those from Ap- sites.

More $\mathrm{Ni}$ was found in the bodies of grasshoppers, spiders, and other invertebrates from Ap+ sites than in their counterparts from Ap- sites (Fig. 1). The difference was statistically significant for all three invertebrate groups (Mann Whitney U test: $\mathrm{P}=0.009$ for grasshoppers, $\mathrm{P}=0.011$ for spiders, $\mathrm{P}=0.009$ for others). There were no significant differences $(\mathrm{P}>0.05)$ between the Ap+ and $\mathrm{Ap}$ - sites in the amounts of $\mathrm{Cr}$ or Co in the bodies of any of the animals sampled.

\section{Discussion}

The metal concentrations of Alyssum pintodasilvae foliage confirm previous findings (de Varennes et al. 1996) that this species hyperaccumulates only nickel, and does not take up exceptional concentrations of other metals even if these are freely available. The differences in soil metals between the $\mathrm{Ap}+$ and Ap- sites are consistent with the typical elemental composition of serpentine rocks (Brooks 1987), and suggest that while soils at both types of sites were derived from serpentine minerals, the former were more strongly ultramafic. Our data support this geological explanation rather than phytoenrichment of metals by hyperaccumulator leaf litter (Boyd and Jaffré 2001), in that Ni, Cr, and Co were all significantly higher in Ap+ soils, whereas A. pintodasilvae itself would enrich only the Ni. Conversely, it is unlikely that the elevated Ni levels measured in animals from Ap+ sites resulted from adhering dust and soil particles, as there was no concurrent elevation in $\mathrm{Cr}$ and $\mathrm{Co}$ in these animals, as would be expected from mineral contaminants.

Because A. pintodasilvae hyperaccumulates Ni selectively and to high concentrations, it is most likely that this species was the source of the elevated $\mathrm{Ni}$ detected in the invertebrates. Wall and Boyd (2002) came to a similar conclusion with regard to the effects of Streptanthus polygaloides on arthropods in California. We also detected higher $\mathrm{Ni}$ concentration in plants other than A. pintodasilvae at Ap+ sites compared to Ap- sites (Table 2), presumably because of the more strongly ultramafic soils at the former. While this difference was statistically significant (Mann-Whitney $\mathrm{U}$ test: $\mathrm{P}=0.013$ ), it was not of great magnitude, and the $\mathrm{Ni}$ concentrations in such plants were 10 to 100 times lower than those measured in the bodies of the animals. Thus, it seems unlikely that these other plants were responsible for the observed Ni concentrations in the animals. The specific results described here might differ had the collections been made on a different date, due to seasonal variations in metal uptake by the hyperaccumulator and differences in the floral and faunal characteristics of the sites.

The highest concentration of Ni that we observed in animals at Ap+ sites was in the "other invertebrates" category, with mean Ni concentration exceeding $1300 \mu \mathrm{g} \mathrm{g}^{-1}$, a remarkably high value that would qualify as hyperaccumulation if it were in plant tissues. This heterogeneous category consisted primarily of several unidentified species of relatively large-bodied Heteroptera, along with various mantids, flies and ants. It is unlikely that all of them would accumulate high nickel concentrations; therefore, one or more species probably has a much higher concentration in order to bring the mean up to this value. Our ongoing studies are attempting to identify these insect taxa and assign nickel concentrations to individual species. In similar systems Schwarz \& Wall (2001) have recently described a new species of Heteroptera that specializes on a $\mathrm{Ni}$ hyperaccumulator, Streptanthus polygaloides (Brassicaceae), in California, and accumulates $590-1020 \mu \mathrm{g} \mathrm{g}^{-1} \mathrm{Ni}$ in its tissues. On the other hand, a beetle that specializes on the South African Ni hyperaccumulator Berkheya coddii (Asteraceae) does not accumulate high Ni levels in its body tissues (MesjaszPrzybylowicz et al. 2002). 


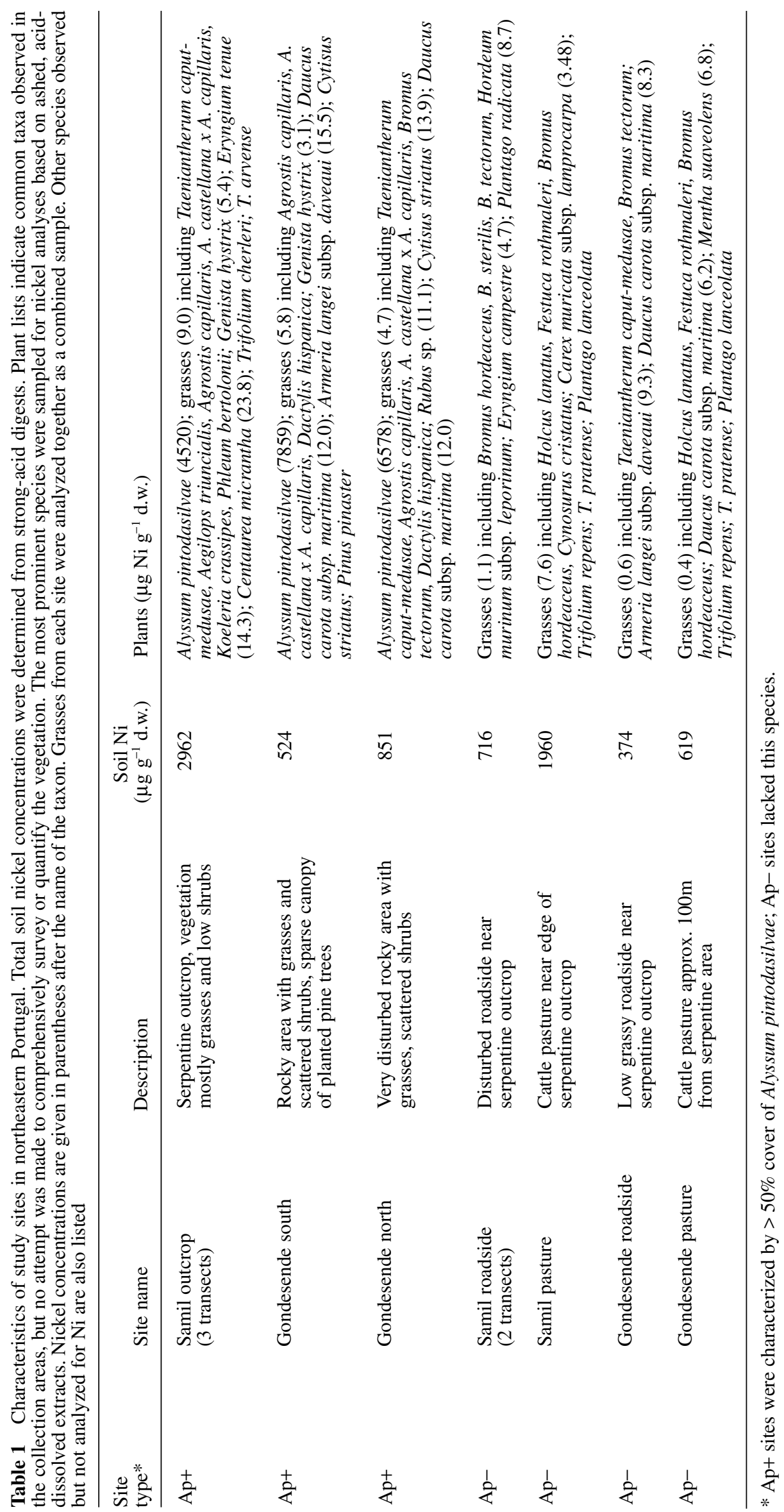


Table 2 Nickel, chromium, and cobalt concentrations in plant and soil samples from Portuguese serpentine sites. Values shown are means \pm standard errors, averaged across the 5 sites of each type

\begin{tabular}{llcrr}
\hline & & \multicolumn{3}{c}{ Concentration $\left(\mu \mathrm{g} \mathrm{g}^{-1}\right.$ dry weight $)$} \\
\cline { 3 - 5 } $\begin{array}{l}\text { Site } \\
\text { Type* }\end{array}$ & Sample & $\mathrm{Ni}$ & $\mathrm{Cr}$ & $\mathrm{Co}$ \\
\hline Ap+ & Soil & $2052.1 \pm 264.4$ & $748.0 \pm 90.3$ & $116.4 \pm 11.0$ \\
Ap+ & Alyssum pintodasilvae & $5599.5 \pm 1254.3$ & $2.5 \pm 0.6$ & $6.8 \pm 2.7$ \\
Ap+ & All other plants & $11.1 \pm 2.1$ & $2.1 \pm 0.8$ & $0.3 \pm 0.2$ \\
Ap- & Soil & $876.8 \pm 137.8$ & $503.2 \pm 35.1$ & $71.2 \pm 6.5$ \\
Ap- & All plants & $5.1 \pm 0.3$ & $1.4 \pm 0.2$ & $0.2 \pm 0.1$ \\
\hline
\end{tabular}

$*$ Ap+ sites were characterized by $>50 \%$ cover of Alyssum pintodasilvae; Ap- sites lacked this species

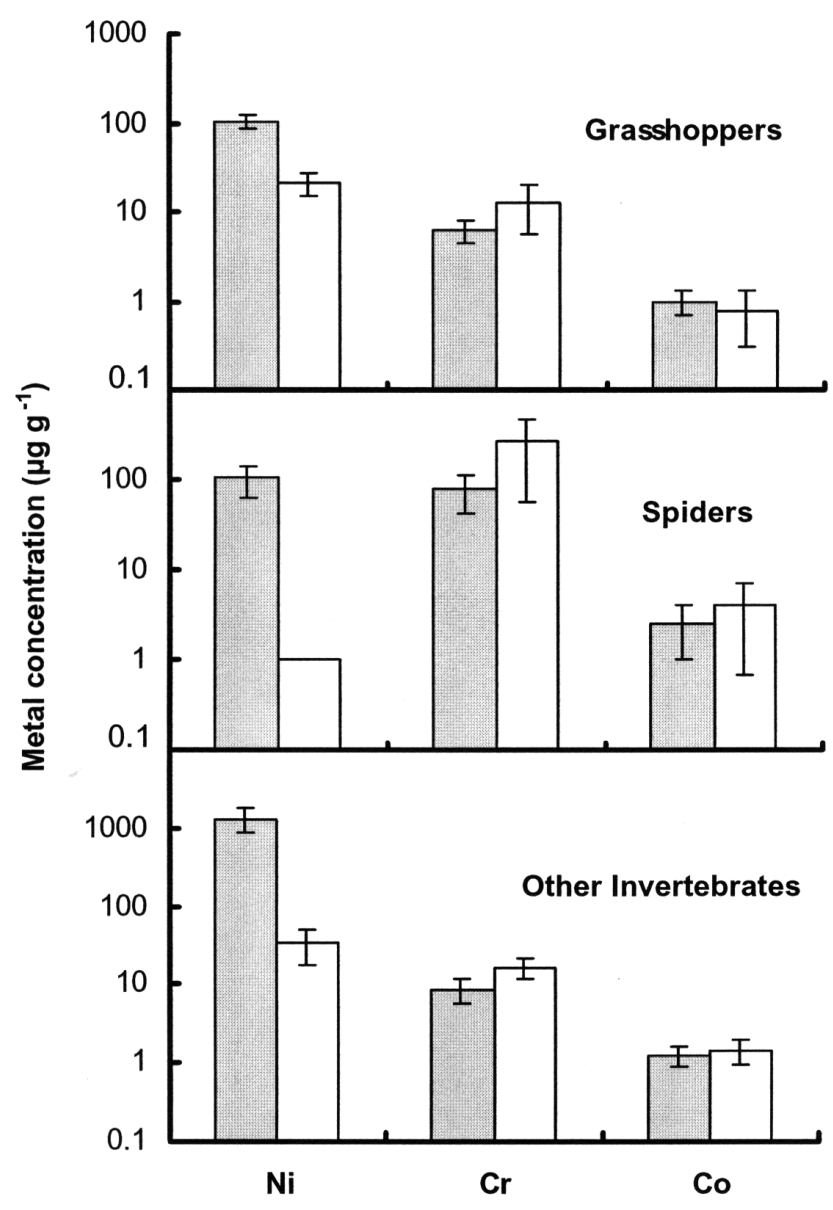

Fig. 1 Mean elemental concentrations of invertebrate samples from serpentine sites in northeastern Portugal. Shaded bars represent "Ap+ sites" in which the Ni-hyperaccumulator Alyssum pintodasilvae was the dominant vegetation. Open bars are "Ap- sites" where this species was not present. The vertical axes are scaled logarithmically in order to avoid obscuring lower values. Error bars indicate standard errors of means

High Ni concentrations in both grasshoppers and spiders suggest that the presence of hyperaccumulating plants affects the flux of Ni to both herbivore and carnivore trophic levels. This parallels findings recently published by Boyd and Wall (2001) showing that nickel accumulated by a herbivore feeding on hyperaccumulating plants can be passed on to the bodies of carnivores. Their study mostly involved feeding experiments in captivity, in which animals were reared on a single diet with no choices. Our data extend this finding to a natural situation, in which both herbivores and carnivores were feeding freely on foods with a variety of metal concentrations. In one case, Boyd and Wall (2001) reported the nickel concentration in wild-caught crab spiders (Misumena vatia, Araneae: Thomisidae) from Streptanthus polygaloides on California serpentines. The maximum $\mathrm{Ni}$ concentration they reported, $110 \mu \mathrm{g} \mathrm{g}^{-1}$, was similar to our mean value for spiders of $103.1 \mu \mathrm{g} \mathrm{g}^{-1}$. This similarity is made more intriguing by the fact that our samples were also primarily made up of thomisid crab spiders, especially Xisticus cristatus but also some M. vatia.

The mean $\mathrm{Ni}$ concentration that we found in spiders (103.1 $\mu \mathrm{g} \mathrm{g}^{-1}$ ) was very close to that in grasshoppers $\left(103.3 \mu \mathrm{g} \mathrm{g}^{-1}\right)$. If these figures are taken as representative of general concentrations of $\mathrm{Ni}$ in herbivore and carnivore trophic levels, their ratio represents a biomagnification index (Laskiowski 1991, Boyd \& Wall 2001) of $\mathrm{B}=0.998$. Values of this index near unity indicate that, once an element enters the food chain, it is transferred but is not further concentrated or "magnified." In this respect our result agrees with previous findings for nickel and most other metals (Heliövaara \& Väisänen 1987, Outridge \& Sheuhammer 1993, Barceloux 1999, Chaney et al. 2000).

We did not attempt to determine what portion of the nickel measured in the arthropods had been assimilated into body tissues, as opposed to residing in gut contents. Apart from the difficulty of separating these tissues, we also wanted the results to be relevant to predators that consume whole prey, including the gut contents. The limited data on toxicological effects of dietary nickel toward vertebrates suggests that foraging in systems such as this could harm insectivorous animals. Grasshoppers are a major component of arthropod biomass (Devkota \& Schmidt 2000), and the concentrations of Ni observed in their tissues approach the level at which mammals and birds become unable to regulate their absorption and excretion of this element (Outridge \& Sheuhammer 1993). The concentrations found in the "other invertebrates" category could be acutely toxic to wildlife (Cain \& Pafford 1981).

Although our study was intended to mimic the situation of a phytoremediation monoculture, it differs in several ways. Most importantly, the hyperaccumulator A. pintodasilvae is endemic to this vegetation, and herbivores and carnivores have had the opportunity to adapt, in both the physiological and evolutionary senses, to its presence. Short-term introduction of metal accumulating plants to 
communities in which they do not normally occur could have different consequences. There is mounting evidence that hyperaccumulated metals may act as defenses against herbivory, either by acute toxicity (Boyd \& Martens 1994, Boyd 1998) or by deterrence of feeding (Pollard \& Baker 1997, Jhee et al. 1999). Even in systems without hyperaccumulators, grasshoppers have been shown to avoid feeding on plants contaminated by heavy metal pollution (Migula \& Binkowska 1993). Thus, in systems that are not co-adapted, trophic transfer of metals may be less common than demonstrated in our studies. On the other hand, our results point out the possibility that a technique used to clean up pollutants in the environment could potentially spread these materials through food chains at hazardous concentrations instead. We recommend that phytoremediation and phytomining schemes incorporate regular sampling and monitoring of metal concentrations in both invertebrate and vertebrate herbivores at the sites. Such data may determine whether measures such as trapping, exclusion, or insecticide treatments are warranted to avoid herbivory on metal-rich plant material. Herbivores represent a potential loss of yield as well as an entry point into food chains; therefore, these steps could increase both the safety and the efficiency of phytoremediation.

\section{Acknowledgments}

We thank J.A.C. Smith and M.J. Miranda for help and support. Financial support to L.R.P. and A.J.P. was provided by the South Carolina Independent Colleges and Universities.

\section{References}

Aguiar C, Penas A, Lousã M (1998) The non rupicolous, endemic communities of the ultramafic rocks of "Tras-os-Montes" (NE Portugal). Itinera Geobot 11:249-261

Baker AJM, McGrath SP, Reeves RD, Smith JAC (2000) Metal hyperaccumulator plants: a review of the ecology and physiology of a biological resource for phytoremediation of metal-polluted soils. Pp 85-107 in Terry N, Bañuelos GS (eds) Phytoremediation of contaminated soil and water. USA, FLBoca Raton: CRC Press

Barceloux DG (1999) Nickel. Clinical Toxicol 37:239-258

Boyd RS (1998) Hyperaccumulation as a plant defensive strategy. Pp 181-201 in: Brooks RR (ed) Plants that hyperaccumulate heavy metals. USA, NY-New York: CAB International

Boyd RS, Jaffré T (2001) Phytoenrichment of soil Ni content by Sebertia acuminata in New Caledonia and the concept of elemental allelopathy. S Afr J Sci 97:535-538

Boyd RS, Martens SN (1992) The raison d'être for metal hyperaccumuation by plants. Pp 279-289 in Baker AJM, Proctor J, Reeves RD (eds) The vegetation of ultramafic (serpentine) soils. GB-Andover: Intercept Ltd.

Boyd RS, Martens SN (1994) Nickel hyperaccumulated by Thlaspi montanum var. montanum is acutely toxic to an insect herbivore. Oikos 70:21-25

Boyd RS, Martens SN (1998) The significance of metal hyperaccumulation for biotic interactions. Chemoecology 8:1-7

Boyd RS, Wall MA (2001) Responses of generalist predators fed high-Ni Melanotrichus boydi (Heteroptera: Miridae): elemental defense against the third trophic level. Am Midl Nat 146:186-198

Brooks RR (1987) Serpentine and its vegetation. USA, ORPortland: Discorides Press
Brooks RR, Chambers MF, Nicks LJ (1998) Phytomining. Trends Plant Sci 3:359-362

Brooks RR, Shaw S, Asensi Marfil A (1981) The chemical form and physiological function of nickel in some Iberian Alyssum species. Physiol Plant 51:167-170

Cain BW, Pafford EA (1981) Effects of dietary nickel on survival and growth of mallard ducklings. Arch Environ Contam Toxicol 10:737-745

Chaney RL, Malik M, Li YM, Brown SL, Brewer EP, Angle JS Baker AJM (1997) Phytoremediation of soil metals. Curr Opin Biotech 8:279-284

Chaney RL, Li YM, Brown SL, Homer FA, Malik M, Angle JS, Baker AJM, Reeves RD, Chin M (2000) Improving metal hyperaccumulator wild plants to develop commercial phytoextraction sytems: approaches and progress Pp 129-158 in Terry N, Bañuelos GS (eds) Phytoremediation of contaminated soil and water. USA, FL-Boca-Raton: CRC Press

Chiarucci A, Robinson BH, Bonini I, Petit D, Brooks RR, De Dominicis V (1998) Vegetation of Tuscan ultramafic soils in relation to edaphic and physical factors. Folia Geobot 33:113-131

Cunningham SD, Ow DW (1996) Promises and prospects of phytoremediation. Plant Physiol 110:715-719

De Varennes A, Torres MO, Coutinho JF, Rocha MMGS, Neto MMPM (1996) Effects of heavy metals on the growth and mineral composition of a nickel hyperaccumulator. J Plant Nutr 19:669-676

Devkota B, Schmidt GH (2000) Accumulation of heavy metals in food plants and grasshoppers from the Taigetos Mountains, Greece. Agric Ecosyst Environ 78:85-91

Dudley TR (1986) A new nickelophilous species of Alyssum (Cruciferae) from Portugal, Alyssum pintodasilvae T. R. Dudley. Fedd Rep 97:135-138

Heliövaara K, Väisänen R (1987) Heavy metal levels in two biennial pine insects with sap-sucking and gall-forming life-styles. Environ Pollut 48:13-23

Jhee EM, Dandridge KL, Christy AM, Pollard AJ (1999) Selective herbivory on low-zinc phenotypes of the hyperaccumulator Thlaspi caerulescens (Brassicaceae). Chemoecology 9:93-95

Laskiowski R (1991) Are the top carnivores endangered by heavy metal biomagnification? Oikos 60:387-390

Mesjasz-Przybylowicz J, Przybylowicz W, Ostachowicz B, Augustyniak M, Nakonieczny M, Migula P (2002) Trace elements in the chrysomelid beetle (Chrysolina pardalina) and its Ni-hyperaccumulating host-plant (Berkheya coddii). Fresen Environ Bull 11:78-84

Migula P, Binkowska K (1993) Feeding strategies of grasshoppers (Chorthippus sp.) on heavy metal contaminated plants. Sci Tot Env 1993 suppl:1071-1083

Outridge PM, Sheuhammer AM (1993) Bioaccumulation and toxicology of nickel: implications for wild mammals and birds. Environ Rev 1:172-197

Pollard AJ (2000) Metal hyperaccumulation: a model system for coevolutionary studies. New Phytol 146:179-181

Pollard AJ, Baker AJM (1997) Deterrence of herbivory by zinc hyperaccumulation in Thlaspi caerulescens (Brassicaceae). New Phytol 135:655-658

Pollard AJ, Dandridge KL, Jhee EM (2000) Ecological genetics and the evolution of trace element hyperaccumulation in plants Pp 251-264 in Terry N, Bañuelos GS (eds) Phytoremediation of contaminated soil and water. USA, FL-Boca-Raton: CRC Press

Reeves RD, Baker AJM (2000) Metal-accumulating plants Pp 193-229 in Raskin I, Ensley BD (eds) Phytoremediation of toxic metals: using plants to clean up the environment USA, NY-New York: John Wiley \& Sons

Salt DE, Baker AJM (2001) Phytoremediation of metals. In Rehm HJ, Reed G (eds) Biotechnology, vol. 11b: Environmental Processes II, Soil Decontamination. Pp 386-397. USA NY-New York: Wiley VCH

Schwartz MD, Wall MA (2001) Melanotrichus boydi, a new species of plant bug (Heteroptera: Miridae: Orthotylini) restricted to the nickel hyperaccumulator Streptanthus polygaloides (Brassicaceae). Pan-Pac Entomol 77:39-44 
Schwitzguébel JP, van der Lelie D, Baker A, Glass DJ, Vangronsveld J. (2002) Phytoremediation: European and American trends. J Soils Sediments 2:91-99

US Dept of Energy (1994) Summary report of a workshop on phytoremediation research needs. DOE/EM-0224. USA, VA-Springfield: National Technical Information Service
Wall MA, Boyd RS (2002) Nickel accumulation in serpentine arthropods from the Red Hills, California. Pan-Pac Entomol 78:168-176

Received 22 August 2002; accepted 2 April 2003.

(12) To access this journal online:

